\title{
Investigating the Behavior of Iran's Light Crude Oil Price in Short Term
}

\author{
Seyed Abdollah Razavi ${ }^{1}$, Mostafa Salimifar ${ }^{2}$, Seyed Mahdi Mostafavi ${ }^{3} \&$ Mortaza Baky Haskuee $^{4}$ \\ ${ }^{1}$ Ph.D. student, Department of Economics, Faculty of Economics and Business Administration, Ferdowsi \\ University Of Mashhad \\ 2 Professor of Economics, Department of Economics, Faculty of Economics and Business Administration, \\ Ferdowsi University Of Mashhad \\ 3 Assistant Professor of Economics, Department of Economics, Faculty of Economics and Business \\ Administration, Ferdowsi University Of Mashhad \\ ${ }^{4}$ Assistant Professor of Economics, Faculty of Economics, University of Allameh Tabatabai \\ Correspondence: Mostafa Salimifar, Professor of Economics, Department of Economics, Faculty of Economics \\ and Business Administration, Ferdowsi University Of Mashhad. E-mail: mostafa @um.ac.ir \\ Received: December 10, 2015 \\ Accepted: January 10, 2016 \\ Online Published: January 13, 2016 \\ doi:10.5539/mas.v10n3p45 \\ URL: http://dx.doi.org/10.5539/mas.v10n3p45
}

\begin{abstract}
Investigate the causes of changing the oil price and modeling for predicting its volatility has always been one of the most important fields of Iran's economic literature study due to its position in Iran's economy. On the other hand, oil price volatility lead to the difficulty in the development programs. Empirical studies show that oil prices volatility are caused the structural bottlenecks (trade balance bottleneck, budget bottlenecks, etc.) in Iran's economic.

Understanding the mechanism of oil prices formation can reduce the risk of oil price volatility and its negative impacts on Iran's economy. With the development of oil bourse and oil futures market, oil market changed the crude oil price formation so that the cash flow between financial markets and oil market will deviant the crude oil price from its long term direction by changing in interest rate in short-term. In this paper, it is investigated the crude oil price deviation from its long-term direction with regard to the relationship between mentioned markets in short-term. For this purpose, Fisher price jump model and Frankel theory will be used for test by using daily time series data of 2005-13 about Iran's light crude oil in different areas (different markets), as well as multivariate GARCH technique method. Also, the results show that the pricing strategy is false signal in the use of Urals crude oil in the determining of crude oil price in the Mediterranean and North West Europe markets.
\end{abstract}

Keywords: Iran's light crude oil, ICE, Urals crude oil, stock market index and interest rate

\section{Introduction}

Extreme volatility of oil prices was led the numerous disruptions in the world market of oil and therefore in the world economy in the late twentieth century. Many stocks that oil speculators imported to the market to use the windfall profits, were caused that major oil producers are affected more than any other group, because the index of crude oil pricing were always in change. And this volatility not only affected on their sale market in the spot market but also would cause to affect the obtained revenue from sales of their long-term contracts that was also established base on the same index, and manufacturers' revenue faces with instability. Also according to the vital role of volatility in financial markets has been considerable attention to the analysis of volatility forecasts in recent years.

Portfolio managers, traders and dealers all are interested to the volatility forecast, with a reasonable level of accuracy for achieving higher profit or lower risk situation. This paper seeks to investigate the impact of financial markets on the behavior of Iran's light crude oil price in the market of East regions, North West Europe and Mediterranean. It can be considered the necessity and importance of the research in this that high share of oil revenues in GDP in Iran, as well as high dependence of government budget to oil revenues has been caused that any volatility in world prices of oil creates severe disorders in development plans and annual plans of the country, which in turn is led to structural bottleneck in the long term.

On the other hand, oil price volatility leads to problem in the development plans. Empirical studies show that oil 
prices volatility is caused structural bottleneck (bottlenecks in the trade balance, budget bottlenecks, etc.) in Iran's economic. Understanding the mechanism of oil prices formation can reduce the risk of oil price volatility and its negative impacts on Iran's economy. In the first part of this article, the influencing channels of crude oil price, in the second part, the review of literature, in the third part, the theoretical foundations, in the fourth part, Iran's crude oil markets, in the fifth part, used techniques, in the sixth part, presenting variables and research findings and in the final part the research conclusion will be investigated.

\subsection{Different Channels of Influencing}

In this section, it is investigated and determined the influencing channels of research major variables on each other theoretically.

A - By supply:

According to the exploitation from exhaustible natural resources, exploiter follows to maximize the present value of withdrawal profit from stocks during the period of exploitation. So the withdrawal rate for each period is determined as the net present value of profit maximizes in different periods.

On the basis the net present value of future profit reduces, and increases the motivation for withdrawal in the current period. On the other hand, the increase in the interest rate reduces the motivation for maintaining the oil stock (oil on ship). Oil market studies show that one of the influencing factors in determining the oil spot prices is the change in maintained crude oil stock on the ship (Ye, 2006).

Change in oil stock on the ship is a function of maintenance cost that depends on the interest rate. Increase in the real interest rates causes to increase in the maintenance cost of oil on ship which, in turn, reduces the demand for maintenance of oil on ship and then causes to increase supply and reduce of oil price. Since a simple model cannot encompass all the factors affecting oil price, should enter other factors into our model. So one of the factors that influences on the determining the oil price and should be entered the model, is the change in the business stock (Myer, 2006).

B - By demand:

Reduction in the interest rate causes to increase the total demand of US economic and as a result the increase of oil demand in the US. Increase of US demand causes to grow of demand in other economies and as a result the increase of oil demand, that increase in world oil demand causes to increase the crude oil price. For example, the increase of oil price in 2004 and 2006 has been under influence of increasing the demand of countries like China. Economic growth in the consuming countries and as result the growth of economic activities contains the increase in oil demand. Therefore, the more industrial activities in the oil consuming countries, the more oil demand.

\section{C- By the mechanism of financial markets:}

The influencing mechanism of US monetary policy on the process of oil prices formation through the channel of oil bourses is in this form. Change in real interest rate due to monetary policy in the United States causes to change in cash flow between bourse markets of commodity and market of bond and stock. Because the increase in interest rate causes decline in the price of bond and treasury bills and stocks. By reducing the price of the bond increases the opportunity of profit for speculators in the bond market that causes to cash flow from commodity bourses towards markets. Reduce of speculation in commodity bourses, including the oil bourses, causes to reduce the price of oil derivatives (including oil futures). Reduction in the futures price with close maturity reduces the oil spot price drastically (Sadorsk, 1999).

One of the most important issues that was considered at the beginning of the Islamic Revolution, has been the reducing of oil revenues share in the economy, but in spite of such an important issue in the country, peformances have been on other way and over the years, however, release from the share of oil has been approved in the budget in the buduet laws and plan of country but performances is not led to this issue. So that the performance of government has been the indicator of 40 to 68 percent dependence on the general budget of government to oil profits in past years. However, this process shows the reducuing of mentioned share, but in no way can be overlooked 40 percent dependence on the public budget to oil.

\subsection{History of Foreign Studies}

Pindayk (1994) investigates the long-term behavior of US crude oil price in the context of randomized process, and has explained the model of long-term behavior of crude oil price and consistency of model with the real figures of crude oil and then investigates the return of crude oil prices towards its average in the long-tern. He proves from the unit root test that oil prices return towards its average, of course returning time depends on its 
motion and its motion is slow. Thus, a geometric Brownian motion is taken into considered for the price of crude oil. In the view of Pindayk, although OPEC has abled to determine the crude oil prices above the competitive price in times, but in long term, its price is the same competitive price.

Yousefi and Virjanto (2004) have investigated an empirical method for determining the formation of crude oil price to identify the reaction of the OPEC countries to dollar rate exchanges against other major currencies and the prices of other members. In this paper, using regression method GMM, the impact of US dollar rate volatility is measured on the formation of the OPEC oil price.

Frankel (2008) has investigated the behavior of crude oil price and, then has divided factors affecting the behavior of crude oil price into two categories: short term (financial factors) and long term (fundamental factor). Using empirical tests show that the long-term trend of world price of oil is influenced by fundamental factors such as supply and demand, change in the capacity of oil producing countries, as well as change in commercial stocks of oil.

Wang et al (2013) contrary to the conducted current studies about futures prices and oil spot that is done base on the approach of Johansen (1988), have used the nonlinear error correction model of threshold to consider the nonlinear dynamics in adjustments related to the balance point. The research results show that the relationship between futures prices and spot has been co-integration provided that the differences in price is greater than the threshold values, as well as in long-term the futures prices and spot (both) are effective in the long-term adjustment and its related dynamics.

\subsection{Background of Internal Studies}

Keshavarzian and colleagues (2010) investigated the relationship between the dollar and the oil price in the form of long-term and short-term periods. The mentioned relationship is investigated by demand and supply of crude oil structurally. The results of their studies show that causality in US dollar rate market and oil price in the long term has been one-sided and from the exchange market to oil market and not vice versa.

Mohajeri (2011) has investigated the relationship of crude oil prices in spot and futures markets and the impact of stock and risk of adjusted basis on the interest rate of financial markets on changes of mentioned prices with the method of monthly time series data of commercial stocks of crude oil and risk of adjusted basis related to spot price and futures of WTI crude oil in the period of 1986 to 2010.

Becky and colleagues (2014) forecast the volatility of oil futures markets using GARCH models and Markov switching GARCH models. The empirical results of this study using obtained data WTI oil futures show that significantly MRS-GARCH model has a higher performance to forecast the volatility of GARCH usual model in the short-term time horizons.

\section{Theoretical Foundations}

Schuch (1974) pointed to the importance of macroeconomic and financial factors role on the price of agricultural products for the first time. But in all subsequent articles, the exchange rate was known the only mechanism of transmitting monetary policy to the price of agricultural products. Chambers and Just studies (1981 and 1982) are such this. However, the importance of the exchange rate should not affect this subject and consider it as less importance. Monetary policy (changing of real interest rate), even in a closed economy also affects the price of products such as agricultural products and other basic commodities. The theory indicates the relationship between interest rate and the real spot price of oil over the long-term trend. In the framework of this theory, when interest rate increases, the extraction of natural resources increases. The increase in oil supply intensifies the reduction of oil price. This process continues until the beneficiaries (exporters) believe that oil price closes to final cost of withdrawal. In this situation, there is the expect of increasing the real oil price so exports reduce and real price of oil increases to reach the long-term adjusted level. The current model is the model of investigating the effect of monetary policy (changing of real interest rate) on basic commodities such as oil. The model shows the negative impact of real interest rate and the positive impact of the expected growth rate of money supply.

Stevens (1995) argues that there have been developments in the oil market from 1980 onwards and by forming and expanding the oil bourses, oil market has changed to the competitive market and the mechanism of forming the crude oil price has changed that have increased the prices. On the other hand, the increase in non-OPEC production has intensified the price volatility and mechanism of forming prices has changed basically after 1980 . In such a way that the previous models of forming crude oil prices cannot justify the changes in this period therefore it is necessary to form models to include new conditions in them.

Frankel (2010) states one of the important factors in explaining the behavior of crude oil price in short term can be attributed changing in interest rate so that in short term changing in interest rate causes deviation in the 
direction of crude oil price from the balance way. The process is created by changing in interest rate that is mainly due to the monetary policy of open market in Federal Reserve, for example reducing of interest rate is a factor in order to encourage the increasing of bonds purchase, which in turn its price increases due to the increase of demand for bonds. Because bond price has inverse relationship with interest rate of bonds, causing the leading of cash flow to the futures market, and its price increases. In the meantime, the decision on purchase of spot or future of crude oil in particular will be taken into consideration to purchasers. Thus, if the obtained cost of maintaining the crude oil is more than the profit in the futures market, deal with to purchase the future contracts. The reverse can also happen. So it can be said first the interest rate is caused volatility in the bond market by changing in the monetary market and then has affected future markets, stock and oil. Therefore, in short term, changes in interest rate causes the price deviance from the long-term direction, this means that long-term behavior is determined by fundamental factors, but in short term may be the price is lower or higher than the long-term direction that is due to changes of rate interest.

In short, the monetary policy causes to change in interest rate and then is effective on the price of basic commodities such as agricultural commodities and oil, although the price of basic commodities is flexible. But because the price of other commodities (industrial goods) is sticky, monetary policy affects the price of basic commodities. In short term reduction in the level of money supply causes to increase the real interest rate and thus causes to reduce the price of basic commodities. Change in basic commodities price is more than change in the money supply. In other words, basic commodities price will be diverted from its long-term direction.

\section{Iran's Light Crude Oil Markets}

\subsection{East Market (Asia market)}

Crude oil indicators in the market is as follows:

1. Dubai crude oil is with degree of API, 30 and sulfur content of 1.9 that its monthly average price for the first month of the future market of Dubai is used to determine the crude oil price of Persian Gulf such as crude oil of Iran, Saudi Arabia, Kuwait and Mexico's isthmus in Far East market and Asia.

2. Crude oil of Oman index is with the degree of API, 34 and sulfur content of 2 that its price will be determined monthly by the Ministry of Oil and Minerals of Oman. It is known that Oman's crude oil price is evaluated in publications such as Platts only as spot price in the forward market. Prices that are published for Oman in the market, representing sale price differential of Oman spot to the country's formal monthly price in the market. Formal prices of crude oil are monthly and retroactive, that resulting in average of Oman spot trading in last month. The monthly average of Oman prices in the market is used to determine the price of cargos in the market of Far East, Asia and even Africa.

Iran's light and heavy crude oil, Lavan blend, Fruzan and Siri blend in the market are supplied as FOB Ports of Khark, Lavan and Siri to the world markets and in pricing, are function of crude oil such as Oman and Dubai for the destinations of Asia. Accordingly, in the regional markets can be argued that Iran's crude oil in the East (Asia) market is determined based on the average of Dubai oil price and Oman.

\subsection{Raised Crude Oil in the Mediterranean Market}

The index of Russian Urals crude oil market is with gravity of 32 degree and sulfur content of 1.4. In this region, sale of this crude oil is as safe Port Augusta in Sicily, Italy. Origins of crude oil exports to this region are the port of Novorossiysk and ports in Ukraine in Odessa Sea. The major customers of this crude oil are France, Italy and Spain, which in some cases occupied Palestine, is also the major customers of this crude oil in the Mediterranean market. Although in many oil producers for its crude oil pricing in this region use this crude oil, but because the price of crude oil is very unstable, cannot be considered as an appropriate index for other crude oil. In some cases the dated Brent crude oil price is used as an index for the crude oil price.

Iran's light crude oil with a gravity of 33 to 34 degree and sulfur content of 1.4 in Sidi Kerir of Egypt is transferred to this region. However, a few years due to lack of supply this crude oil as spot in Mediterranean market, evaluating their prices is carried base on Russia Urals crude oil, if crude oil of Russia should be a function of Iran's crude oil in this region.

\subsection{North West Europe Market}

One of the important crude oil for evaluating index of supplied crude oil in the market is Brent oil that its production is around 480 thousand barrels per day and is deliverable in Sullom Noe port in the North Sea. Its cargo is about 500 thousand barrels of crude oil. This publication for evaluating acted upon the quality difference of this crude oil with the dated Brent. Of course all produced crude oil in the North Sea have quality difference 
to dated Brent.

Another crude oil that is supplied as crude oil of index to evaluate the sour crude oil in this market is Russia Urals crude oil and the gravity of 32 degree of crude oil with sulfur content of 4 is the type of sour crude oil. However, sale of this crude oil in this region, according to crude oil safety due to the leased large tanks, has a high volume in the port of Rotterdam, Netherlands that through the vast network of pipelines is connected to all parts of Europe and its refineries. So by purchasing the cargo and its discharging in the port of Rotterdam, purchasers can transfer it to the consumption centers quickly through the network of pipelines.

\section{Introducing Analysis and Research Technique}

Engle for the first time in 1982 showed that some models can be studied simultaneously, including the conditional average and conditional variance. These models are known as ARCH models (returned conditional heteroskedasticity) that their basis is hidden in the elimination of heteroskedasticity in the studied patterns. The advantage of ARCH models is that, can explain the process of conditional variance due to its past information. In general, $\mathrm{ARCH}$ process q order is provided by the following equations.

In model of generalized ARCH that commonly is called GARCH, both the associated components and components of moving averages appear in variance equation (Enders, 2004). The more savings in the model, the lower number of coefficients limits. One of the obvious advantages of GARCH model is that in some cases instead of a high order ARCH model, GARCH model is replaced that the principle of savings is more considered and, identification and its evaluation is easier. Meanwhile, the simple model GARCH $(1,1)$ provides a thrifty description of the information (Bolerself 1986, MacCurdy and Morgan, 1988). One of the models of multivariate GARCH is BEKK model that is used in investigating the overflow impact. It was introduced first by Engle and Kroner (1995).

\section{Variables and Results}

To study the phenomenon of overflow in the international energy market, data of daily price related to oil and financial markets is used during 2005 and 2013. The following statistical source is from the National Oil Company international affairs. The software Eviews 8 is used to estimate the variable. The used variables in this study are as follows:

BRDTD: crude oil spot price of dated Brent. Brent: crude oil spot price of Brent. Dubail: crude oil spot price of Asia index. Oman1: crude oil spot price of Asia index. S \& P500: index of capital market. R: US interest rate. LNWE: Iran's light crude oil price in North West Europe market. LMED: Iran's light crude oil price in the Mediterranean market. LEAST: Iran's light crude oil price in East market. Urals: crude oil, Urals, Rotterdam. URM: Urals crude oil in the Mediterranean. ICE Brent crude oil weighted average in paper market.

\section{Behavior Analysis of Iran's Light Crude Oil Price in the Markets}

\subsection{Behavior Analysis of Iran's Crude Oil Price in the East (Asia) Market}

To study the behavior of Iran's crude oil price in East market and the impact of price volatility in other oil including Oman and Dubai crude oil, which is traded in the market on behavior of Iran's crude oil price, a multivariate GARCH model is used. Therefore, two states are considered. In the first case, according to conducted studies by Mebru (1994), it is assumed that Dubai and Oman crude oil is a function of North Sea Brent Sea crude oil.

$$
\begin{aligned}
\log (\text { Least })= & \alpha_{1}+\alpha_{2} \log \text { mean }+\alpha_{3} \log \mathrm{R}+\alpha_{4} \log \mathrm{S} \& P_{500}+\mathrm{e}_{\mathrm{t}} \\
\log \mathrm{Oman}_{1}= & \beta_{1}+\beta_{2} \log \text { Brent }+\beta_{3} \log \mathrm{R}+\beta_{4} \log \mathrm{S} \& P_{500}+\mathrm{e}_{\mathrm{t}} \\
\log \text { Dubai }= & \gamma_{1}+\gamma_{2} \log \text { Brent }+\gamma_{3} \log \mathrm{R}+\gamma_{4} \log \mathrm{S} \& P_{500}+\mathrm{e}_{\mathrm{t}} \\
& \sigma_{t}^{2}(\mathrm{i})=\mathrm{M}(\mathrm{i})+\mathrm{A} 1(\mathrm{i}) e_{t-1}^{2}+\mathrm{B} 1 \text { (i) } \sigma_{t-1}^{2}
\end{aligned}
$$

To investigate the variability of Iran's crude oil price in the East market and impact of volatility any of the traded crude oil in region on Iran's crude oil, the multivariate GARCH model $(1,1)$ is used. Interrupt $(1$ of 1$)$ according to Schwarz criterion is optimal) the results of estimating equations are reported in the following table. 
Table 1. Estimate the behavior of Iran's crude oil price in the Asian market

\begin{tabular}{|c|c|c|c|c|c|c|c|c|}
\hline \multirow{6}{*}{$\begin{array}{l}\text { Average } \\
\text { equations }\end{array}$} & \multicolumn{2}{|r|}{ Constant } & \multicolumn{2}{|c|}{$\log ($ mean $)$} & $\log (\mathrm{R})$ & $\log \left(S_{2} P_{500}\right)$ & \multicolumn{2}{|c|}{ Brent1 } \\
\hline & $\log ($ LEAST $)$ & $\begin{array}{r}-0.154 \\
(-14.188)\end{array}$ & \multicolumn{2}{|c|}{$\begin{array}{l}1.014 \\
(942.645)\end{array}$} & $\begin{array}{l}-0.005 \\
(-6.707)\end{array}$ & $\begin{array}{l}0.015 \\
(8.428)\end{array}$ & - & \\
\hline & $\log \mathrm{Oman}_{1}$ & 0.169 & \multirow{2}{*}{\multicolumn{2}{|c|}{ 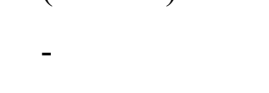 }} & -0.039 & -0.006 & \multirow{4}{*}{\multicolumn{2}{|c|}{$\begin{array}{l}0.977 \\
(370.191) \\
0.976 \\
(102.589)\end{array}$}} \\
\hline & & (11.076) & & & $(-27.718)$ & $(-2.325)$ & & \\
\hline & log Dubai 1 & - & \multirow{2}{*}{\multicolumn{2}{|c|}{ - }} & -0.051 & 0.019 & & \\
\hline & & & & & $(-10.443)$ & (3.116) & & \\
\hline \multirow{4}{*}{$\begin{array}{l}\text { Variance } \\
\text { equations }\end{array}$} & $M$ & & \multicolumn{2}{|l|}{$A$} & $B$ & & & \\
\hline & $\begin{array}{c}\times 10^{-8} 3.91 \times 1 \\
10^{-7} \times 2 / 3 \\
(0.028)(-0.622)\end{array}$ & $\begin{array}{l}0^{-8} \\
(5.190)\end{array}$ & -3.21 & $\begin{array}{l}0.305 \\
(18.845)\end{array}$ & 0 & $\begin{array}{l}0.968 \\
(513.643)\end{array}$ & \multicolumn{2}{|l|}{$0]$} \\
\hline & {$\left[\begin{array}{cc}0 & 1 . \\
(5 / 792) & \end{array}\right.$} & $48 \times 10^{-5}$ & & 0 & $\begin{array}{c}0.473 \\
(19.840)\end{array}$ & $\begin{array}{l}0 \\
(79.669)\end{array}$ & \multicolumn{2}{|c|}{.864} \\
\hline & $\begin{array}{l}0 \\
(4.964)\end{array}$ & 0 & \multicolumn{2}{|c|}{$\begin{array}{ll}0.01 & 0 \\
& (9.114)\end{array}$} & 0 & $\begin{array}{l}0 \\
31.843\end{array}$ & \multicolumn{2}{|l|}{0} \\
\hline
\end{tabular}

Source: research findings

All model coefficients statistically are significant and coefficients signs are as expected. Based on the estimated results, elasticity of Iran's light crude oil compared to the average of Oman and Dubai crude oil is positive and equal to 1.014. In order to evaluate the impact of interest rate volatility and index of capital market, these two variables are imported in the equation of Iran's crude oil pricing. As expected, the results show that elasticity of Iran's light oil price to interest rate is -0.005 and statistically is significant, indicating that by rising cost of maintenance, storage of demand for Iran's light crude oil increases in the Asian market.

Each oil market is a market of monopolistic competition, so each market has its own supplier in Asia market, if here is spoken about the markets of crude oil, it means that Iran's crude oil market is Iran's crude oil in per geographic region that are sold.

In addition, Iran's crude oil price elasticity to stock market is positive and equal to 0.015 , which suggests that by economic growth and development of markets and economic growth, the demand for Iran's crude oil in Asia increases. The coefficient of this variable is positive as expected.

In Oman and Dubai crude oil equations in the same manner, crude oil price elasticity is positive to Dubai crude oil. In addition, the price elasticity of two oils compared to interest rate is negative and compare to stock market index is positive. Coefficients of variance equations show that volatility in each crude oil markets of Iran, Dubai and Oman has a positive and significant impact on each of the other markets. Matrices A and B show the shocks changes and volatility in each markets on other markets.

In order to test the impact of GARCH, after estimating any multivariate GARCH models, must ensure the optimal modeling the leavings of simultaneous equations model by this model that optimality condition of model is lack of unequal variance of this model, because in truth the mentioned way is used for modeling the variance heterogeneous nature of simultaneous equations model, and elimination of the nature of variance heterogeneity in this system is with the condition of variance consistency in leavings of multivariate GARCH model. Hence for the evaluation of lack of variance heterogeneity the leavings of this model, the variance ratio test is used.

Table 2. Evaluating the test of GARCH impact

\begin{tabular}{lrrr}
\hline Equations & & The range of statistic Z & Possibility level \\
\cline { 4 - 4 } \cline { 3 - 3 } Eqaution1 & & 6.947 & 0.000 \\
Equation2 & The maximum statistic Z & 8.456 & 0.000 \\
Equation3 & & 82.335 & 0.000 \\
\hline
\end{tabular}

Source: Research findings

\subsection{Investigation the Behavior of Iran's Light Crude Oil in the Mediterranean market}

In order to analyze the behavior of Iran's crude oil, two presented scenarios based on the views of experts are 
discussed and investigated (Mabro, 1994). In the first scenario, arguing that Iran's crude oil price is a function of the weighted average of dated Brent crude oil that among market experts is known as ICE BWAVE Pricing. In addition, we assume Iran's crude oil price is a function of environmental conditions, including changes in US interest rate (which determine the cost of shipping and maintenance), the stock market index. The crude oil price behaviors of Mediterranean Urals and Brent are a function of economic variables, including interest rate and stock market index. On this basis by increasing interest rate expected to reduce the demand for index crude oil and finally the price decreases, so interest rate is considered as a negative factor in the formation of the crude oil price. It is also by improving the economic situation and the resulting growth of the capital market index, the demand for Iran's crude oil increases in the Mediterranean market. Therefore, it is forecasted that stock market index and mentioned crude oil price is positive. Based on this, for mentioned crude oil, we have the following equations:

$$
\begin{gathered}
\log \left(\text { LMED }_{t}\right)=\alpha_{0}+\alpha_{1} \log \left(\mathrm{ICE} 1_{t}\right)+\alpha_{2} \log \left(R_{t}\right)+\alpha_{3} \log \left(S \& P 500_{t}\right)+e_{t 1} \\
\log \left(\mathrm{BRDTD}_{\mathrm{t}}\right)=\beta_{0}+\beta_{1} \log \left(R_{t}\right)+\beta_{2} \log \left(S \& P 500_{t}\right)+e_{t 2} \\
\log \left(\mathrm{URM}_{\mathrm{t}}\right)=\gamma_{0}+\gamma_{1} \log \left(R_{t}\right)+\gamma_{2} \log \left(S \& P 500_{t}\right)+e_{t 3} \\
\sigma_{t}^{2}(\mathrm{i})=\mathrm{M}(\mathrm{i})+\mathrm{A} 1(\mathrm{i}) e_{t-1}^{2}+\mathrm{B} 1(\mathrm{i}) \sigma_{t-1}^{2}
\end{gathered}
$$

To investigate the variability of Iran's crude oil price in the Mediterranean market and impact of volatility any of the traded crude oil in region on Iran's crude oil, the multivariate GARCH model $(1,1)$ is used. (Interrupt (1 of 1) is selected according to Schwarz criterion) the results of estimating equations are reported in the following table:

Each oil market is a market of monopolistic competition, so according to table (1)estimate of Iran's crude oil behavior has its own supplier in Asia market, if here is spoken about the markets of crude oil, it means that Iran's crude oil market is Iran's crude oil in per geographic region that are sold.

Table 3. Estimate of Iran's crude oil price in the Mediterranean market

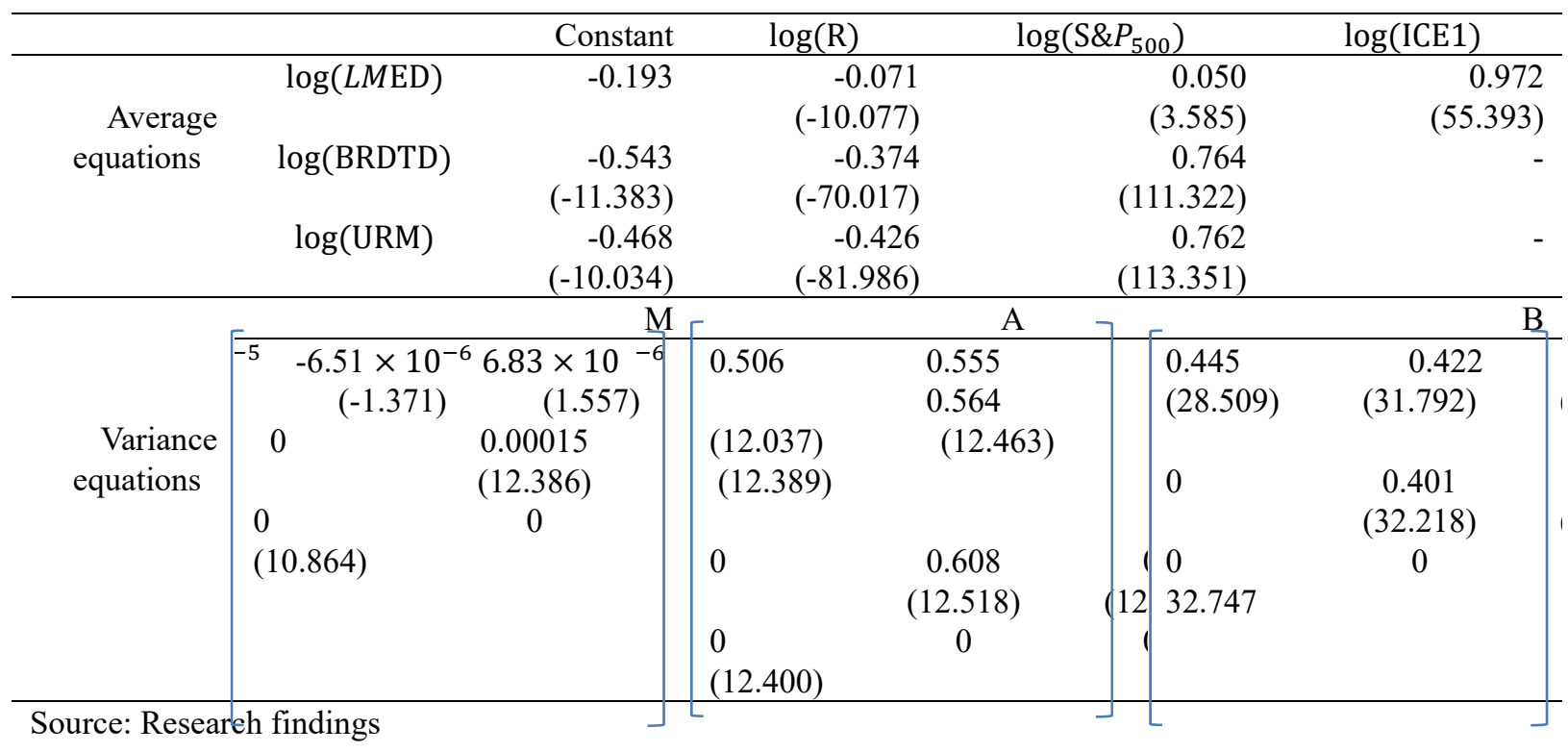

As expected, the coefficients of interest rate and stock market index have respectively positive and negative symbols. Also the results indicate that variable coefficient ICE is positive and the elasticity of Iran's crude oil price compared to ICE is 0.9 it means that by increasing one percent ICE causes to increase nine percent in Iran's crude oil price in the Mediterranean market. The coefficients related to variance equations show that any momentum in the market has a positive impact on price volatility in other markets. The coefficients in the matrix A are all positive and statistically significant and positive; the coefficients represent the impact of change in one standard deviation in one market to other markets. Since all the coefficients are matrix A, is indicative of the fact that any momentum in a market which is causing volatility in other markets, that show the positive impact of overflow among the markets. Also, coefficients of matrix B are positive and significant, which show that volatility in a market is with volatility in other markets as well. Multivariate GARCH model was used to 
evaluate the test, the null hypothesis was not confirmed, and as the following table.

Table 4. Evaluating the test of GARCH impact

\begin{tabular}{llrr}
\hline Equations & & The range of statistic Z & Possibility level \\
\cline { 4 - 4 } Eqaution1 & \multirow{2}{*}{ The maximum statistic Z } & 8.204 & 0.000 \\
Equation2 & & 80.504 & 0.000 \\
Equation3 & 81.861 & 0.000 \\
\hline
\end{tabular}

Source: Research findings

As was explained at the beginning of this part, among oil experts argue that Iran's light crude oil price is a function of Brent and Urals crude oil difference. The second scenario is as before, except that instead of ICE using, the difference of Urals and dated Brent is used. For this purpose, multivariate GARCH model is considered with the same previous conditions.

$$
\begin{gathered}
\log \left(\mathrm{LMED}_{\mathrm{t}}\right)=\alpha_{0}+\alpha_{1} \log \left(\mathrm{DIFUB}_{\mathrm{t}}\right)+\alpha_{2} \log \left(\mathrm{R}_{\mathrm{t}}\right)+\alpha_{3} \log \left(\mathrm{S} \& P 500_{\mathrm{t}}\right)+\mathrm{e}_{\mathrm{t} 1} \\
\log \left(\mathrm{BRDTD}_{\mathrm{t}}\right)=\beta_{0}+\beta_{1} \log \left(\mathrm{R}_{\mathrm{t}}\right)+\beta_{2} \log \left(\mathrm{S} \& P 500_{\mathrm{t}}\right)+\mathrm{e}_{\mathrm{t} 2} \\
\log \left(\mathrm{URM}_{\mathrm{t}}\right)=\gamma_{0}+\gamma_{1} \log \left(\mathrm{R}_{\mathrm{t}}\right)+\gamma_{2} \log \left(\mathrm{S} \& P 500_{\mathrm{t}}\right)+\mathrm{e}_{\mathrm{t} 3} \\
\sigma_{\mathrm{t}}^{2}(\mathrm{i})=\mathrm{M}(\mathrm{i})+\mathrm{A} 1(\mathrm{i}) \mathrm{e}_{\mathrm{t}-1}^{2}+\mathrm{B} 1(\mathrm{i}) \sigma_{\mathrm{t}-1}^{2}
\end{gathered}
$$

To investigate the variability of Iran's crude oil price in the Mediterranean market and impact of volatility any of the traded crude oil in region on Iran's crude oil, the multivariate GARCH model $(1,1)$ is used. (Interrupt (1 of 1) is selected according to Schwarz criterion) the results of estimating equations are reported in the following table.

Table 5. Estimate of Iran's crude oil price in the Asian market

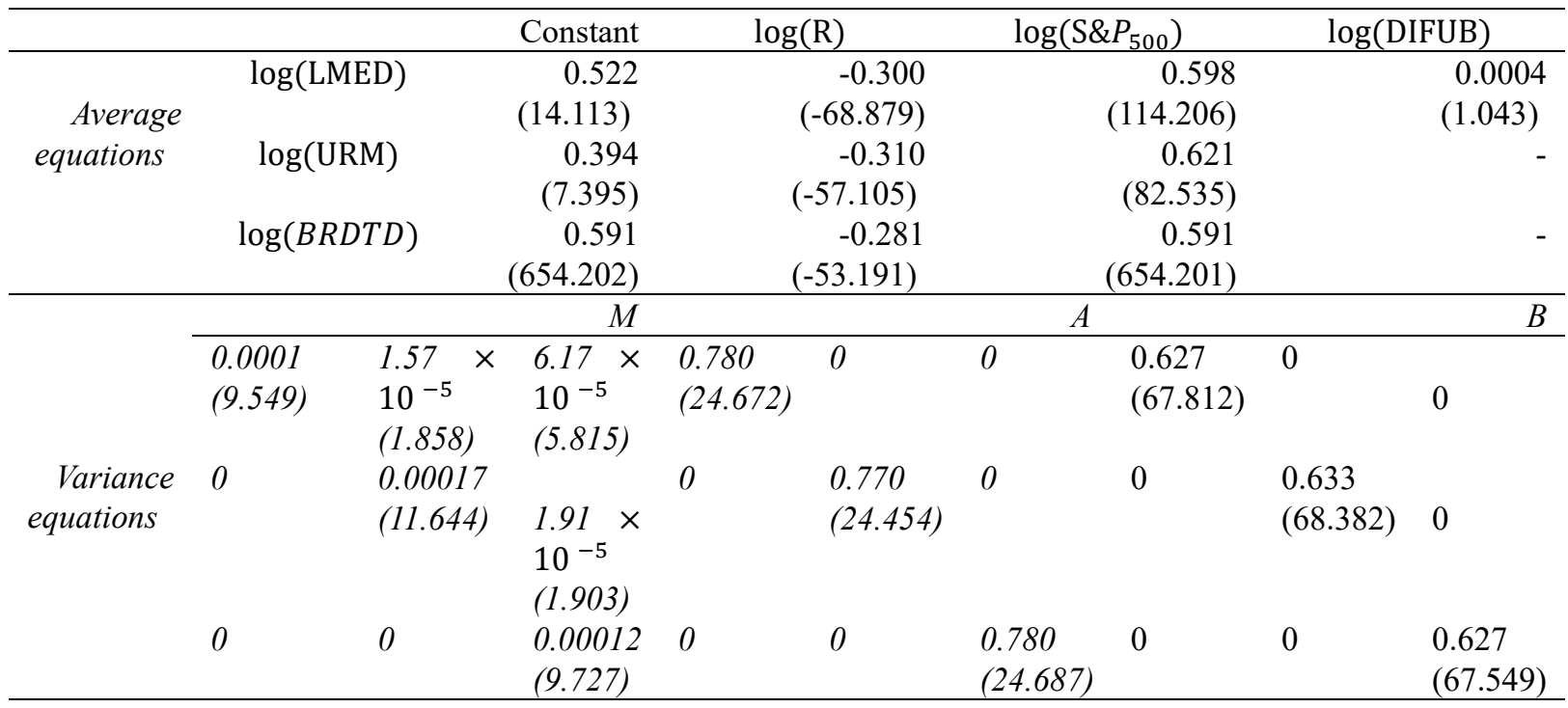

Source: Research findings

As can be seen in the table above, difference of crude oil price of Urals Mediterranean is not significant with Brent and not giving a correct signal about Iran's crude oil price in the region. Also, multivariate GARCH test results are listed below (the null hypothesis was not confirmed):

Table 6. Evaluating the test of GARCH impact

\begin{tabular}{lcrr}
\hline Equations & & The range of statistic $Z$ & Possibility level \\
\cline { 3 - 3 } \cline { 3 - 3 } Eqaution1 & The maximum statistic $Z$ & 0.013 \\
Equation2 & & 2.934 & 0.000 \\
\hline
\end{tabular}




\begin{tabular}{lcc}
\hline Equation3 & 81.910 & 0.000 \\
\hline
\end{tabular}

Source: Research findings

\subsection{Behaivor Analysis of Iran's Crude Oil Price in North West Europe Market}

In North-West Europe market for Iran's light crude oil, we acted the same as the two scenarios of Mediterranean market, in the first scenario, import the Rotterdam Ural difference with Brent, in the second scenario, instead of using the crude oil difference of Urals Rotterdam with dated Brent, ICE BWAVE pricing system is used.

In the first scenario we have the following equation:

$$
\begin{gathered}
\log \left(L N W E_{t}\right)=\alpha_{0}+\alpha_{1} \log \left(\text { DIFUR }_{t}\right)+\alpha_{2} \log \left(R_{t}\right)+\alpha_{3} \log \left(S \& P 500_{t}\right)+e_{t 1} \\
\log \left(B R D T D_{t}\right)=\beta_{0}+\beta_{1} \log \left(R_{t}\right)+\beta_{2} \log \left(S \& P 500_{t}\right)+e_{t 2} \\
\log \left(U R R_{t}\right)=\gamma_{0}+\gamma_{1} \log \left(R_{t}\right)+\gamma_{2} \log \left(S \& P 500_{t}\right)+e_{t 3} \\
\sigma_{t}^{2}(i)=M(i)+A 1(i) e_{t-1}^{2}+B 1(i) \sigma_{t-1}^{2}
\end{gathered}
$$

To investigate the variability of Iran's crude oil price in North West Europe, multi Varit GARCH method is used. In the following table the results are:

Table 7. Estimate the behavior of Iran's crude oil price in the Mediterranean market

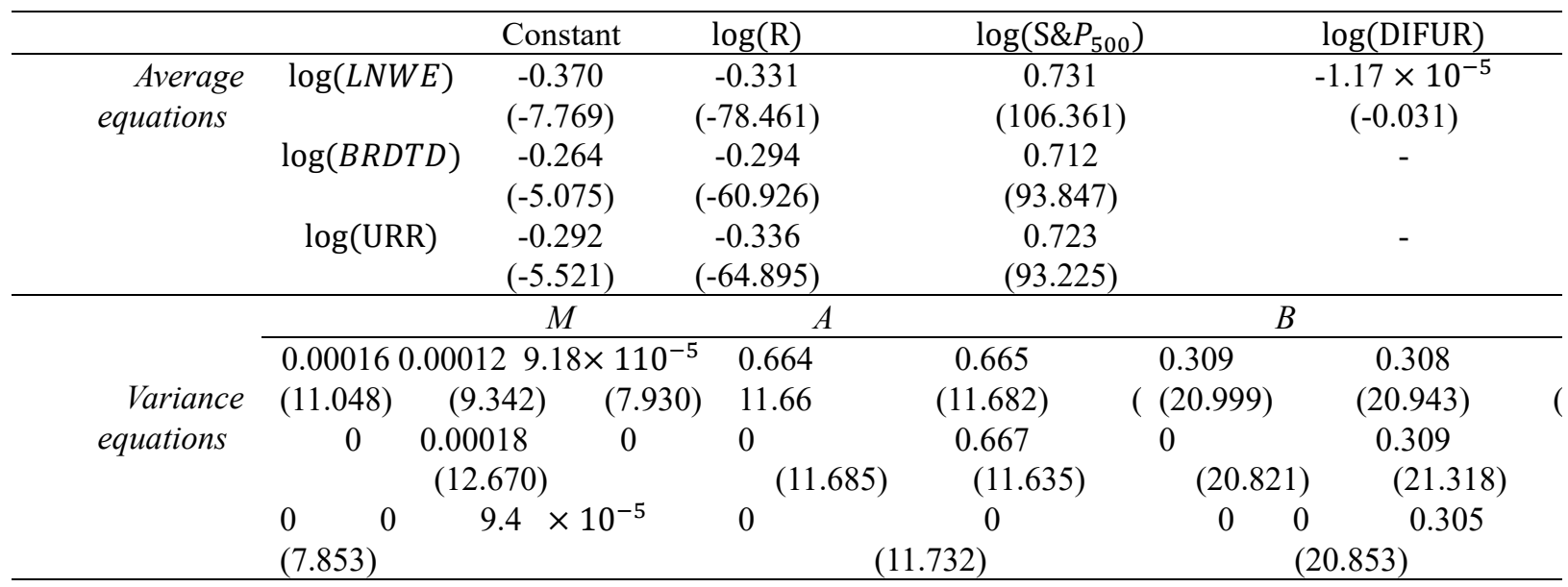

Source: Research finding

As can be seen, all coefficients are statistically significant (except the variable coefficient of Brent crude oil difference with Urals Rotterdam) and mark of values is as expected. Interest rate in three above equations - 0.331 , -0.294 and -0.336 as expected with crude oil is negative and statistically significant. The stock market index, coefficients are as follows $0.731,0.712$ and 0.723 , which as expected there is a positive relationship between the mentioned index and discussed crude oil which show that by growth of the stock market index, the demand for crude oil increases in the market and as result the price of crude oil also goes up. On the other hand, the international affairs experts of National Iranian Oil Company believe that Iran's crude oil in this region is a function of the difference between Brent crude oil and Urals Rotterdam as can be seen, the difference between Brent and Urals Rotterdam is not significant, indicating that the use of crude oil in crude oil pricing is causing false signals.

In the above variance equations with a unit, the shock level in the Urals market in this market causes volatility in the price of Iran's light crude oil in the level of 0.665, On the other hand, with a unit, the shock level in the Brent market causes volatility of Iran's crude oil price in level of 0.656 units. Also with a unit, the shock level in the Urals market causes volatility in level of 0.657 units. As it was observed using the price of oil crude hasn't given correct signals to explain the behavior of Iran's light crude oil price in this region. GARCH test results as explanations of Asian market that its null hypothesis wasn't also confirmed, is as follows:

Table 8. Evaluating the test of GARCH impact 
Source: Research findings.

\begin{tabular}{llrr}
\hline Equations & & The range of statistic $\mathrm{Z}$ & Possibility level \\
\cline { 4 - 4 } \cline { 3 - 3 } Eqaution1 & The maximum statistic Z & 2.979 & 0.000 \\
Equation2 & & 4.593 & 0.000 \\
Equation3 & & 81.305 & 0.000 \\
\hline
\end{tabular}

In the second scenario the following equations are used to explain the behavior of Iran's light crude oil price:

$$
\begin{gathered}
\log \left(L N W E_{t}\right)=\alpha_{0}+\alpha_{1} \log \left(I C E 1_{t}\right)+\alpha_{2} \log \left(R_{t}\right)+\alpha_{3} \log \left(S \& P 500_{t}\right)+e_{t 1} \\
\log \left(\mathrm{BRDTD}_{\mathrm{t}}\right)=\beta_{0}+\beta_{1} \log \left(\mathrm{R}_{\mathrm{t}}\right)+\beta_{2} \log \left(\mathrm{S} \& P 500_{\mathrm{t}}\right)+\mathrm{e}_{\mathrm{t} 2} \\
\log \left(\mathrm{URR}_{\mathrm{t}}\right)=\gamma_{0}+\gamma_{1} \log \left(\mathrm{R}_{\mathrm{t}}\right)+\gamma_{2} \log \left(\mathrm{S} \& P 500_{\mathrm{t}}\right)+\mathrm{e}_{\mathrm{t} 3} \\
\sigma_{\mathrm{t}}^{2}(\mathrm{i})=\mathrm{M}(\mathrm{i})+\mathrm{A} 1(\mathrm{i}) \mathrm{e}_{\mathrm{t}-1}^{2}+\mathrm{B} 1(\mathrm{i}) \sigma_{\mathrm{t}-1}^{2}
\end{gathered}
$$

To investigate the variability of Iran's crude oil price in North West Europe market and the impact of volatility in

\begin{tabular}{|c|c|c|c|c|c|c|c|c|c|}
\hline \multirow{7}{*}{$\begin{array}{r} \\
\text { Average } \\
\text { equations }\end{array}$} & \multicolumn{3}{|r|}{ Constant } & \multicolumn{2}{|c|}{$\log (\mathrm{R})$} & \multicolumn{2}{|c|}{$\log \left(\mathrm{S} \& P_{500}\right)$} & \multicolumn{2}{|c|}{$\log$ (ICE1) } \\
\hline & \multicolumn{2}{|c|}{$\log (\mathrm{LNWE})$} & -0.295 & \multirow{2}{*}{\multicolumn{2}{|c|}{$\begin{array}{r}-0.067 \\
(-7.495)\end{array}$}} & \multirow{2}{*}{\multicolumn{2}{|c|}{$\begin{array}{c}0.116 \\
(5.758)\end{array}$}} & \multirow{2}{*}{\multicolumn{2}{|c|}{$\begin{array}{r}0.892 \\
(33.731)\end{array}$}} \\
\hline & & & $(-7.771)$ & & & & & & \\
\hline & \multicolumn{2}{|c|}{$\log (\mathrm{BRDTD})$} & -0.350 & \multirow{2}{*}{\multicolumn{2}{|c|}{$\begin{array}{r}-0.300 \\
(-59.198)\end{array}$}} & \multirow{2}{*}{\multicolumn{2}{|c|}{$\begin{array}{r}0.725 \\
(95.406)\end{array}$}} & & \\
\hline & & & $(-6.745)$ & & & & & & \\
\hline & \multirow{2}{*}{\multicolumn{2}{|c|}{$\log (\mathrm{URR})$}} & -0.369 & \multirow{2}{*}{\multicolumn{2}{|c|}{$\begin{array}{r}-0.342 \\
(-67.153)\end{array}$}} & \multirow{2}{*}{\multicolumn{2}{|c|}{$\begin{array}{r}0.734 \\
(92.135)\end{array}$}} & & - \\
\hline & & & $(-6.802)$ & & & & & & \\
\hline \multirow{5}{*}{$\begin{array}{l}\text { Variance } \\
\text { equations }\end{array}$} & \multicolumn{3}{|c|}{$M$} & \multicolumn{2}{|c|}{$e_{2}$} & \multicolumn{4}{|c|}{$B$} \\
\hline & $\begin{array}{l}0.0001 \\
(38.089)\end{array}$ & $\begin{array}{l}3.05 \\
10^{-6}\end{array} \times$ & $60_{10^{-5}} \times$ & $\begin{array}{c}0.898 \\
(14.182)\end{array}$ & 0 & 0 & $\begin{array}{c}0.136 \\
(9729)\end{array}$ & 0 & 0 \\
\hline & & $(0.269)$ & $(6.858)$ & & & & & & \\
\hline & 0 & $\begin{array}{l}0.0003 \\
(20.177)\end{array}$ & $\begin{array}{l}0.0002 \\
(12.717)\end{array}$ & 0 & $\begin{array}{c}0.952 \\
(14.491)\end{array}$ & 0 & 0 & $\begin{array}{c}0.1364 \\
(10.251)\end{array}$ & 0 \\
\hline & 0 & 0 & $\begin{array}{l}0.0004 \\
(19.911)\end{array}$ & 0 & 0 & $\begin{array}{c}0.953 \\
(14.709)\end{array}$ & 0 & 0 & $\begin{array}{c}0.042 \\
(4.760)\end{array}$ \\
\hline
\end{tabular}
any of the traded crude oil in the region on Iran's crude oil, the multi Varit method of GARCH is used. Above equations results have been reported in the following table.

Table 9. Estimate the behavior of Iran's crude oil price in the Mediterranean market

Source: Research findings.

All coefficients are statistically significant and coefficients signs are as expected. As expected, the coefficients of interest rate in three markets of crude oil $(-.0342,-0.3,-0.06)$ is negative. The coefficients of stock market index in accordance with raised theories were $0.743,0.116$ and 0.725 , which are positive as expected. The interest rate is considered as a negative factor in the development of Iran's crude oil price. It is also by improving the economic situation and as a result, growth of the stock market index, the demand for Iran's crude oil in the North-West Europe market increases so as forecasted, stock market index and mentioned crude oil price is positive. The results also indicate that coefficient ICE is positive and elasticity of Iran's crude oil price compared to ICE is 0.89 that by increasing of one percent ICE causes to increase of eighty-nine percent of Iran's crude oil price in the market. The following evaluation test doesn't confirm the null hypothesis of multivariate GARCH.

Table 10. Evaluating the test of GARCH impact

\begin{tabular}{lcrr}
\hline Equations & & The range of statistic Z & Possibility level \\
\cline { 3 - 3 } Eqaution1 & & 7.197 & 0.000 \\
Equation2 & The maximum statistic Z & 81.109 & 0.000 \\
Equation3 & & 79.342 & 0.000 \\
\hline
\end{tabular}

Source: Research findings. 


\section{Summary and Conclusion}

As it was raised in the theoretical foundation about the behavior of crude oil price, with respect to the relations of financial markets with oil market can be said in short-term by changing in interest rate as a result of monetary policy in the money market for example tightening policy, the interest rate increases since in the bond market, bond price has inverse relationship with interest rate, the price increases and causes to increase demand for it. By increasing demand for bonds, its price also increases and interest rate reduces. These volatility causes to the transfer of cash flow to the futures market, that in its turn, futures price also increases. This issue that individual acts about the operating in futures market or spot causes to his comparison between the cost of crude oil storage and operating profit in the futures market. At the beginning of the issue, causes to price deviation of crude oil from its long-term direction. The results of empirical test for Iran's light crude oil in markets of East regions, the Mediterranean and North West Europe show that the relationship of mentioned crude oil and money markets (interest rate) is negative in studied regions and on the other hand the relationship between capital market and Iran's crude oil market is positive in its sale regions. The mentioned crude oil price in the markets has a direct and positive relationship with crude oil price of index (in terms of geographical region). Thus it can be said the growth of the capital market index increases the demand for Iran's crude oil in the studied markets thus, as forecasted capital market index and mentioned crude oil price is positive and suggests that by economic growth and development of markets and economic growth, the demand increases for Iran's crude oil in markets. As expected, the results show that Iran's light oil price elasticity than interest rate in studied markets is negative and statistically is significant, indicating that by rising cost of maintenance and storage, the demand for Iran's light crude oil in target markets will increase.

As in the Mediterranean and North West Europe markets were observed the difference of the crude oil price of Brent and Urals Mediterranean and Rotterdam were not significant in explaining the behavior of Iran's light crude oil price and were wrong signal, with regard to the pricing in Iran's crude oil in the mentioned markets, these indicators are used such as weighted average of Brent crude oil price or Brent difference and Urals crude oil according to the studied regions, according to the present study, the difference between Brent and Urals is not significant and recommended that the National Oil Company revises in the use of this index in pricing in these regions.

\section{References}

Arouri, M., \& Nguyen, D. K. (2010). Oil prices, Stock markets and portfolio investment: evidence from sector analysis in europe over the last decade. Energy policy, 38, 4528-4539.

Baki, H. M., \& Khaje, V. F. (2014). Forecasting the volatility of oil futures markets. Journal of financial knowledge of analyzing exchange, 23, 75-108.

Chen, Y. C., \& Rogoff, K. (2003). Commodity Currencies Journal of International Economics, 60, 133-160.

Cologni, A. \& Manera, M. (2008). Oil Prices, Inflation and Interest Rates in a Structural cointegrated var model for the G-7 countries. Energy economics, 30, 856-888.

Cremer, J., \& Salehi, E. (1991). The Rise and Fall of Oil Prices: A Competitive View. Working Paper, University of Pennsylvania, Phil.

Enders, W. (2004). Applied econometric time series. University of Alabama, U.S.A.

Ferderer, J. P. (1996). Oil price volatility and the macroeconomy. Journal of Macroeconomics, 18, 1-26.

Filis, G., Degiannakis, S., \& Floros, Ch. (2011). Dynamic correlation between stock market and oil prices: The case of oil-importing and oil-exporting countries. International review of financial analysis, 20.

Frankel, J. (2006). The Effect of Monetary Policy on the Real Commodity Prices. NBER working paper, 12713.

Guo, H., \& Kliesen, K. L. (2005). Oil price volatility and US macroeconomic activity, Review-federal reserve bank of St.Louis, 57, 669-683.

Hamilton, J. D. (1994). Time series analysis. Princeton university press.

Horsnell, P. (1990). Oil price differentials:markets in disarray (5rd ed.). Oxford: Oxford Institute for Energy Studies.

Huang, B. N., Yang, C. W., \& Hwang, M. J. (2009). The dynamics of a nonlinear relationship between the crude oil spot and the futures prices: A multivariate threshold regression approach. Energy economics, 31(1), 91-98.

Kameli, A. R. (2009). Theory of crud pricing. In N. Hossieni (Ed.), Medhanism of crude oil trandings in physical 
markets. (pp. 49-62). Tehran: Institute for International Energy Studies (IIES).

Karpoff, J. M. (1987). The relation between price changes and trading volume: A survey. Journal of financial and quantitative analysis, 22(1), 109-126.

Kaufmann, \& Robert, K. (2011). The role of market fundamentals and speculation in recent price changes for crude oil. Energy policy, 39(3), 105-115.

Kenneth, R. (2002). Dornbusch's overshooting model after 25 years. IMF second annual research conference.

Keshavarzian, M., \& Zamani, M. (2010). Overflow impact of America dollar exchange rate on the price of crude oil. Journal of Energy Economics Studies, 27, 131-150.

Kipici, A. N., \& Kesriyeli, M. (1997). The real exchange rate definitions and calculations. Central bank of the republic of Turkey.

Lardic, S., \& Mignon, V. (2006). The impact of oil prices on gdp in european countries: an empirical investigation based on asymmetric cointegration, Energy policy, 34, 3910-3915.

Martell, T. F., \& Wolf, A. S. (1987). Determinants of trading volume in futures markets. The journal of futures markets, 7(3), 233-44.

Mohajeri, P. (2011). Investigating the relationships of spot price and future of crude oil WTI. Journal of Economic Modeling Research, 5, 75-102.

Myers, A., \& Soligo, R. (2002). The role of inventories in oil market stability. The quarterly review of economics and finance, 42(2), 401-415.

Namit, S. (1998). Forecasting oil price volatility. Thesis submitted to the faculty of the Virginia Polytechnic Institute and State university.

Park, J., \& Ratti, R. A. (2008). Oil price shocks and stock markets in the U.S. and 13 European countries. Energy economics, 30(5), 2587-2608.

Pindyck, \& Robert, S. (2001). The dynamics of commodity spot and futures markets: a primer. The energy journal, 22(3), 1-29.

Sadorsky, P. (1999). Oil price shocks and stock market activity. Energy Economics, 21(5), 449-469.

Shuddhasawtta, R., Ruhul, S., \& Bloch, H. (2009). Impact of crude oil price volatility on economic activities: An empirical investigation in the Thai economy. Resources policy, 34, 121-132.

Taylor, J. S., \& Spriggs, J. (1989). Effects of monetary macro-economy on canadian agricultural prices, The Canadian journal of economics, 22(2), 278-289.

Teece, D. (1982). OPEC behavior: an alternative view. In J. M. Ž. Griffin (Ed.), OPEC Behavior and World Oil Prices. Allen \& Unwin, London.

Ye, M., Zyren, J., \& Shore, J. (2006). Forecasting short-run crude oil price using high-and low-inventory variables. Energy policy, 34(17), 2736-2743.

Yousefi, A., \& Wirjanto, T. S. (2003). Exchange Rate of the U.S. Dollar and the J Curve: the Case of Oil Exporting Countries. Energy Economics, 25, 741-765.

\section{Copyrights}

Copyright for this article is retained by the author(s), with first publication rights granted to the journal.

This is an open-access article distributed under the terms and conditions of the Creative Commons Attribution license (http://creativecommons.org/licenses/by/3.0/). 